\title{
Üslü İfadelerde Yaşanan Kavram Yanılgılarının Olası Nedenleri ve Önlem Önerilerinin Öğretmen Adaylarının Görüsşlerine Dayalı Olarak İncelenmesi ${ }^{1}$
}

\author{
Investigation the Possible Causes and The Prevention Suggestions of Misconception in The \\ Exponential Expressions Based on The Views of The Preservice Teachers
}

\section{Nurcan SATAN ${ }^{2}$, Kübra AKSAKAL ${ }^{3}$, Zeynep Sonay AY ${ }^{4}$}

\begin{abstract}
Öz
$\mathrm{Bu}$ çalışmanın amacı üslü ifadeler konusunda yaşanan kavram yanılgılarının olası nedenleri ile bu kavram yanılgılarının önlenmesine yönelik neler yapılabileceğine dair ortaokul matematik öğretmeni adaylarının görüşlerini incelemektir. Araştırmada nitel araştırma yöntemlerinden durum çalışması deseni kullanılmıştır. Çalışma bir devlet üniversitesinde son sınıfta okuyan 29 ortaokul matematik öğretmeni adayı ile gerçekleştirilmiştir. Araştırmada, 'Üslü ifadelerde yaşanan kavram yanılgılarının olası nedenleri için ortaokul matematik öğretmeni adaylarının görüşleri nelerdir?" ve “Üslü ifadelerde yaşanan kavram yanılgılarının önlenmesine yönelik ortaokul matematik öğretmeni adaylarının görüşleri nelerdir?" sorularına yanıt aranmıştır. Veri toplama sürecinde, katılımcılara önce, araştırmacılar tarafından hazırlanan üslü ifadelerde yaşanan kavram yanılgılarını içeren soru formu uygulanmış, kavram yanılgısının olası nedeni ile buna yönelik önlem önerilerini yazmaları istenmiştir. Bir ders saati süren bu uygulamanın ardından gönüllü olan 9 katılımcıyla yazdıkları açıklamalar üzerine detaylı görüşmeler yapılmıştır. Öğretmen adayları tarafından öğrencilerin bilgi eksikliği, üslü ifadelerdeki üs ve tabanın neyi ifade ettiğinin bilinmemesi, üslü ifadenin sayısal olarak açılımının bilinmemesi, öğrencilerin parantezin anlamını ve işlevini bilmemesinin, kavram yanılgılarına neden olabileceği belirtilmiştir. Kavram yanılgılarının önlenmesine yönelik olarak üslü ifadeler ile ilgili daha fazla örnek çözülmesi, üslü ifadeler konusunun başlangıcında taban ve üs gibi kavramlar üzerinde durulması, örüntü kullanılması ve konu anlatılırken çoklu gösterimlerin kullanılması gerektiğini belirtmişlerdir.
\end{abstract}

Anahtar Kelimeler

Üslü ifadeler

Kavram yanılgiları

Ortaokul matematik öğretmeni aday1

\section{Abstract}

The aim of this study is to examine the opinions of middle school mathematics preservice teachers on the possible causes of misconceptions about exponential expressions and precautionary suggestions to prevent these misconceptions. The case study design, one of the qualitative research methods, was used in the study. The study was carried out with 29 middle school mathematics preservice teachers studying in the last year of a state university. In the research, two probing responses were sought: "What are the opinions of middle school mathematics preservice teachers for the possible causes of misconceptions in exponential expressions? " and "What are the opinions of middle school mathematics preservice teachers to prevent misconceptions in exponential expressions?". During the data collection process, the participants were first administered a questionnaire containing the misconceptions experienced in exponential statements prepared by the researchers, and they were asked to write down the possible cause of the misconception and their precautionary suggestions. After this one-hour course, detailed interviews were conducted with 9 volunteers on the statements they wrote. It was stated by the preservice teachers that students' lack of knowledge, not knowing what the exponent and base mean in exponential expressions, not knowing the numerical expansion of the exponential expression, not knowing the meaning and function of the parenthesis, may cause misconceptions. In order to prevent misconceptions, stated that more examples about exponential expressions should be resolved, concepts such as base and exponent should be emphasized at the beginning of the topic of exponential expressions, the use of patterns and multiple representations should be used when explaining the exponential expression.

Keywords

Exponential expressions

Misconceptions

Middle school

mathematics preservice teachers
Başvuru Tarihi/Received

05.01.2021

\section{Kabul Tarihi /Accepted}

03.05.2021

| Araştırma Makalesi / Research Article |

\section{Suggested APA Citation/Önerilen APA Atıf Biçimi:}

Satan, N., Aksakal, K., \& Ay, Z. S. (2021). Investigation the possible causes and the prevention suggestions of misconception in the exponential expressions based on the views of the preservice teachers. Manisa Celal Bayar University Journal of the Faculty of Education, 9(1), 32-48. https://doi.org/10.52826/mcbuefd.853179.

\footnotetext{
${ }^{1}$ Bu çalışmada 2020 yılı öncesine ait veriler kullanıldığı yazarlar tarafından beyan edildiği için etik kurul raporu gerekmemektedir.

2 Matematik Öğretmeni, Millı̂ Eğitim Bakanlığı, Hatay, TÜRKIYE; (Di) https://orcid.org/0000-0002-9910-9481

${ }^{3}$ Matematik Öğretmeni, Millî Eğitim Bakanlığı, Ankara, TÜRKIYE;

${ }^{4}$ Dr. Öğr. Üyesi, Hacettepe Üniversitesi, Eğitim Fakültesi, İlköğretim Matematik Öğretmenliği, Ankara, TÜRKIYY; (D https://orcid.org/0000-0002$\underline{1037-7106}$
} 


\section{GİRIŞ}

Matematik eğitimini etkileyen önemli bileşenlerden biri kuşkusuz öğretmen faktörüdür. Öğretmen bilgisini tanımlayan ve öğretmenlerin sahip olması gereken bilgileri içeren çalışmalar Shulman tarafından yapılmıştır (Shulman, 1986). Buna yönelik olarak matematik öğretmeni adaylarının sahip olması gereken alan ve pedagojik alan bilgisi üzerine araştırmalar yapılmıştır (Hacıömeroğlu, 2009; Türnüklü, 2005). Etkili bir matematik öğretimine yönelik yapılması gerekenler arasında öğrencilerin neyi bildikleri ve gereksinim duyduklarını bilmenin onları daha iyi öğrenmeye teşvik etmek için gerektiği vurgulanmıştır (NCTM, 2000). Öte yandan matematik birçok farklı konuyu içeren bir derstir. Şüphesiz bu konuların öğrenciler açısından zorluk derecesi birbirinden farklıdır. Bu konulardan biri olan üslü ifadeler konusunda öğrencilerin zorlandıkları bilinmektedir (Cengiz, 2006). Üslü ifadeler A $€ R$ ve $n €$ Z+ olmak üzere $n$ tane a sayısının çarpımı a'nın $n$. kuvveti olarak ifade edilmekte ve a.a.a.... $=a^{\text {n }}$ şeklinde gösterilmektedir. Buradaki $a^{\text {n }}$ ifadesinde a taban olarak n'de üs olarak ifade edilmiştir (Özaltun-Çelik, 2016). Öğrenciler üs kavramını ilk kez Matematik Dersi Öğretim Programında 5.sınıf kazanımıyla öğrenmeye başlarlar (MEB, 2018). Öğrenciler 5.sınıfın devamında 6., 7. ve 8.sınıf seviyesinde de üslü ifadeler konusunu öğrenmektedirler. Aşağıda bu kazanımlar sınıf düzeyine göre sırayla verilmiştir.

“Bir doğal sayının karesini ve küpünü üslü ifade olarak gösterir ve değerini hesaplar (5.sınıf), bir doğal sayının kendisiyle tekrarlı çarpımını üslü ifade olarak yazar ve değerini hesaplar (6.sınıf), rasyonel sayıların kare ve küplerini hesaplar (7.sınıf) ve tam sayıların, tam sayı kuvvetlerini hesaplar ve üslü ifadelerle ilgili temel kuralları anlar, birbirine denk ifadeler oluşturur (8.sinıf) (MEB, 2018)."

Matematikte birçok gerçek, üslü ifadelerle temsil edilir (Argün, Arıkan, Bulut ve Halıcıoğlu, 2014). Üslü ifadeler okul matematiği içinde ortaokul konularından, üst düzey matematik konularına bir köprü oluşturur. Köklü ifadeler, üstel fonksiyon, logaritmik ve hiperbolik fonksiyonlar için temel oluşturmaktadır. Matematikte en sık kullanılan cebirsel ifade grubu olan üslü ifadeler, kavram, bağıntı ve formülleri ifade ederken sıklıkla kullanılır. (Argün, vd., 2014). Matematik içindeki bu öneminin yanında, alan yazında üslü ifadeler öğrencilerin sıklıkla hata yaptıkları ve bu hataların kavram yanılgısına dönüşebileceği konulardan birisi olarak görülmektedir (Aydın, 2011; Cengiz, 2006; Özkaya, Konyalığlu ve Gedik, 2013; Sastre \& Mullet, 1998; Özmantar, Bingölbali ve Akkoç, 2008). Kavram yanılgısı alan yazında bir konu hakkındaki uzmanların aynı görüşte oldukları düşünceden uzak olan idrak veya karayış olarak ifade edilmektedir (Özmantar, vd., 2008). Ayrıca kavram yanılgısının öğrenenler ile konuyu öğreten uzman kişiler arasındaki algı değişiklikleri olduğu belirtilmiştir (Smith, diEssa ve Roschelle, 1993). Yaşanan zorluklar ve kavram yanılgılarının üç temel nedenden kaynaklandığı düşünülmektedir ki bunlar; psikolojik, pedagojik ve epistemolojik nedenlerdir (Cornu,1991). Bulunulan dönemin biyolojik özellikleri, bilişsel yapı, kavrama düzeyi, işlem becerisi gibi sayılacak özellikler psikolojik nedenler olarak ifade edilmektedir (Erdem, 2013). Pedagojik nedenlere bakıldığında ders kitapları, konuların programlarda ele alınış biçim ve dizilişleri, öğretim modelleri, modellerin uygulanma biçimleri, öğretmenin kullandığı dil, metafor ve benzetmeler gibi faktörler düşünülmektedir (Bingölbali ve Özmantar, 2012). Son olarak matematik öğreniminde bazı konuların doğasından kaynaklı kavram yanılgılarının olası nedenleri ise epistemolojik nedenler olarak görülmektedir (Cornu, 1991).

Üslü ifadelerle ilgili yapılan çalışmalarda kavram yanılgısı farklı boyutlarda ele alınmıştır. Bazı çalışmalar yaşanan zorluklar (üslü sayının değerini belirleyememe gibi) ve kavram yanılgılarını ele alırken (Aydın, 2011; Bilgin ve Dinç, 2015; Cengiz, 2006; Christou, Pantazi ve Zachariades, 2007; Özkaya vd., 2013; Kutluca, 2009; Özkan ve Özkan, 2012; Saraç, 2016; Sastre ve Mullet, 1998; Weber, 2002), bazıları sayı duyusu bileşenleri bakımından (Bayram ve Duatepe-Paksu, 2015; İymen, 2012; İymen ve Paksu, 2015) incelemiştir. Bazı çalışmalar öğrenciler ile yapılmış (Bayram ve Duatepe-Paksu, 2015; Cengiz, 2006; Christou, vd., 2007; İymen ve Paksu; 2015; Kutluca, 2009; Saraç, 2016; Sastre ve Mullet, 1998) bazıları da öğretmen adayları (Aydın, 2011; Özkaya, 2013) ile yapılmıştır.

Bu çalışmalara bakıldığında, Sastre ve Mullet (1998) çalışmalarında farklı yaş grubundaki öğrencilerin (13-14, 16-17, 18-19) üslü ifadelerdeki taban ve kuvvet büyüklüklerini incelemişlerdir. Bu çalışmada lise öğrencilerinden taban olarak 5, 7 ve 9 değerini kuvvet olarak 2, 3 ve 5 değerini kullanarak oluşturdukları üslü ifadeleri kartlara yazıp, sonra kâğıt-kalem ve hesap makinesi kullanmadan büyüklüklerini karşılaştırıp grafiğe aktarmaları istenmiştir. 
Öğrencilere bu malzemelerin verilmemesinin nedeni ise öğrencilerin üslü ifadelere ilişkin sezgisel tahmin düzeylerini anlamaktır. Bu sebeple öğrencilere cetvel verilerek oluşturdukları bu sayıların cetvelde büyüklüklerini tahmin etmeleri istenmiştir. Çalışmanın genel sonucu olarak öğrencilerin yaş seviyeleri arttıkça üslü ifadelerin büyüklüklerinin tabana ve üsse göre nasıl değiştiğini daha iyi kavradıkları görülmüştür. Ayrıca üslü ifadelerin gerçek değerini daha iyi tahmin edebildikleri de belirtilmiştir. Cengiz (2006) çalışmasında reel sayıların öğretiminde öğrencilerin yanılgılarını ve yanlışlarını tespit etmeyi amaçlamıştır. Yine lise öğrencileri ile yapılan bu araştırmada rasyonel sayılar, üslü ifadeler ve köklü ifadelerle ilgili olmak üzere üç farklı ölçek uygulanmıştır. Araştırmanın sonucunda öğrencilerin rasyonel sayılar, köklü ve üslü ifadeler konularında kuralları karıştırdıkları ve ciddi yanılgılarının olduğu ortaya çıkmıştır. Christou, Pantazi ve Zachariades (2007) ise üslü ifadeleri büyüklükleri açısından birbiriyle karşılaştırma amacıyla bir çalışma yapmışlardır. Çalışmanın örneklemini devlet okulundan okuyan 202 ortaokul öğrencisi oluşturmaktadır. Veriler 20 sorudan oluşan yazılı sorularla ve yarı yapılandırılmış görüşmeler yoluyla toplanmıştır. Bu çalışmada kavramsal değişim ve prototip teorisi ile işlemsel ve kavramsal öğrenme bağlamında üslerin anlaşılma düzeylerini tanımlamak ve analiz etmeyi amaçlamışlardır. Araştırmanın sonucunda ise üç anlayış seviyesinin tanımlanabileceğini göstermişlerdir. Birinci basamakta öğrencilerin üstelleri yorumlamasını doğal sayıları sembolize eden üstel ifadelere dayandığını, ikinci basamakta öğrencilerin mevcut kavramsal yapılarının zenginleştirme süreci olduğunu, son basamakta da doğal sayılarla üstel kavramından oldukça farklı bir kavram olan köklerle birlikte prototip örneklerini genişletmekle kalmayıp aynı zamanda üsleri hesaplamak ve karşılaştırmak için düşüncelerini yeniden organize etme şeklinde tanımlamışlardır.

Matematik öğretmeni adaylarıyla yapılmış çalışmalarda ise Özkaya, Konyalığlu ve Gedik, (2013) yaptıkları çalışmada matematik öğretmen adaylarının üslü ve köklü ifadelerde öğrencilerin yapabilecekleri hatalara yaklaşımlarını incelemişler, hataların oluşum sebepleri hakkında görüşlerini ve çözüm önerilerini belirlemişlerdir. İlköğretim matematik öğretmenliği 4. sınıf öğrencileri ile yapılan çalışmanın sonucunda öğretmenlerin matematik alan bilgisindeki eksiklikleri nedeniyle hataları açıklamada sıkıntı yaşadıkları, hataların sebebinin ise öğretmen etkenli olduğu belirtilmiştir. Üniversite öğrencileriyle yapılan bir diğer çalışmada Aydın (2011) üslü ifadelerle ilgili kavramsal bilgi üzerine odaklanmıştır. Fen Bilgisi Öğretmenliği birinci sınıf öğrencilerinin Genel Kimya II dersi içinde yer alan bazı "Matematik" kavramları ile ilgili kavramsal hataları tespit etmeye çalışılmıştır. Bu matematiksel hataların matematikteki birçok konudan kaynaklandığı söylenmiş ve bu konulardan birinin üslü ifadeler konusu olduğu belirtilmiştir. Bu hataların önlenmesi için Kimya eğitimcilerinin matematik eğitimcileri ile iş birliği içinde eğitim vermeleri önerilmiştir. Matematik kavram hatalarının tespiti konusunda duyarlı olmaları için üslü ifadelerdeki üslü çoklukların birbirine bölünmesi, ondalık ifadeler ve üslü ifadelerin birbiriyle çarpılması gibi işlemlerdeki yapılan hatalardan bahsedilmiştir. Kutluca (2009)'nın yaptı̆̆g çalışmada öğrencilerin ve öğretmenlerin görüşünden yararlanarak dokuzuncu sınıf matematik dersinde öğrencilerin zorlandıkları konular belirlenmiştir. Çalışmanın sonucunda öğrencilerin cebir öğrenme alanı içinde yer alan üslü ifadeler konusunda zorlandıkları belirtilmiştir.

Üslü ifadeler konusu öğretilirken kullanılan öğretim, yöntem ve teknikleri inceleyen araştırmalar da yapılmıştır. Bilgin ve Dinç (2015)'in çalışmasında buluş ve geleneksel yöntemlerle üslü ifadeler konusu işlenip, soru çözdürtmenin mezun öğrencilerin öğrenme düzeyine ve problem çözmedeki becerileri üzerine etkileri araştırılmıştır. Araştırmanın sonucunda beceri testinden alınan puanlar karşılaştırıldığında deney grubunun puanlarının daha yüksek olduğu bulunmuştur. Saraç (2016) çalışmasında öğrencilerin zorlandıkları konulardan biri olan üslü ifadelerin öğretiminde kullanılabilecek iki benzetim örneğini tanıtmıştır. Üslü ifadeler konusunda en sık karşılaşılan kavram yanılgılarından taban ve kuvveti ifade eden sayıları çarpma, pozitif ve negatif sayıların tek-çift kuvvetlerinin işaretlerinin belirlenmesi durumlarına yönelik doktor-hasta ilişkisi ile çamurlu ayakkabılar ve simli iki benzetim kullanılmıştır. Çalışmanın sonucunda öğrencilerin kavram yanılgılarına düşme oranının azaldığı fark edilmiştir. Bu açıdan çalışmanın alana katkı sağladığı söylenebilir.

Üslü ifadeleri sayı duyusu bileşenleri bakımından inceleyen üç çalışma aşağıda verilmiştir. Bu çalışmalarda önceki çalışmalardan farklı olarak üslü ifadeler ile ilgili sayı duyularının sayı duyusu bileşenleri bakımından 
incelenmesi söz konusudur. İymen (2012) çalışmasında 8.sınıf öğrencilerinin üslü ifadeler ile ilgili sorularda sayı duyularının, sayı duyuları bileşenleri bakımından incelemiştir. Christou, Pantazi ve Zachariades'in (2007) geliştirdiği üslü ifadeleri karşılaştırma testi kullanılmış ve bunun sonucunda öğrencilerin kısa çözümler yapmak yerine uzun çözümler yaptıkları görülmüştür. Araştırmanın sonucunda ise öğrencilerin işlemlerin etkisini anlamada sayı duyusunda yetersizliklerinin olduğu bulunmuştur. Bayram ve Duatepe-Paksu (2015) çalışmalarında sekizinci sınıf öğrencilerinin üslü ifadelere ilişkin sayı duyuları ve başarıları arasındaki ilişkisi üzerine çalışmışlardır. Veriler araştırmacı tarafından geliştirilen “Üslü ifadelere yönelik başarı testi” ve İymen (2012)'nin geliştirdiği “Üslü ifadelere yönelik sayı duyusu ölçeği” ile toplanmıştır. Araştırmanın sonucunda sekizinci sınıf öğrencilerinin üslü ifadelerdeki başarıları ile sayı duyuları arasında yüksek bir ilişki bulunmuştur. 8. sınıf öğrencilerinin üslü ifade sorularında sayı duyularını kullanma durumlarının düşük olduğu görülmüştür. İymen ve Paksu (2015) çalışmalarında üslü ifadeler ile ilgili sayı duyusunun, sayı duyusu bileşenleri bakımından incelenmesinde kullanılmasına yönelik bir ölçek geliştirmiştir. Bunun için üslü ifade formlarını içeren taslak ölçek oluşturulmuş, sorular alan yazında belirtilen beş sayı duyusu bileşenine yönelik hazırlanmıştır. Uzman görüşleri ve pilot çalışma ve doğrultusunda taslak forma son hali verilmiştir. Bu ölçeğin geliştirilmesi bu alanda var olan bir boşluğu doldurmuştur çünkü üslü ifadelerin sayı duyusu bakımından incelenmesine yönelik çalışmalar sayı olarak sınırlıdır. Sayılar ve aritmetiğin matematik eğitimindeki konumu düşünüldüğü zaman bunları içeren problem durumlarını anlamlandırarak çözmek için sayıların ve bunlar arasındaki ilişkilerin iyi bilinmesi gerekir. Yapılan bu çalışmaların bu açıdan alan yazına fayda sağladiğı düşünülmektedir.

Yapılan çalışmaların tümü incelendiğinde üslü ifadelerde karşılaşılan zorluklar saptanmış olup bunlara yönelik çözüm önerilerine yer veren çalışmalar yapılmış ancak yaşanan kavram yanılgılarının yaşanmaması için alınabilecek önlemlere yönelik çalışmaların az olduğu görülmüştür. Bunun bir eksiklik olduğu düşünülüp bu amaca yönelik bir çalışmanın gerekliliği üzerinde durulmuştur. Çünkü yanlış bir durumun oluştuktan sonra düzeltilmeye çalışılması, o durumun bir önlemle hiç ortaya çıkmamasından daha güçtür. Öğretmen adayları geleceğin öğretmeni olduklarından kavram yanılgılarına yönelik ne gibi önlem önerileri sunacaklarının önemli olduğu düşünülmektedir. Öğretmen yetiştirme programlarında teorik derslerin yanı sıra bilgi ve becerilerin uygulanabileceği gerçek yaşam durumları ya da gerçeğe yakın sınıf uygulamalarına katılımın öğretmen adaylarının gelişimleri açısından önemli olduğu ifade edilmektedir (Beeth \& Adadan, 2006). Bu çalışmayla öğretmen adaylarına olan bir durumun nedenini ve bu duruma yönelik alabileceği önlemleri düşünmesi ve bu konuda kendini değerlendirme fırsatı oluşturulmaktadır. Çalışmanın amacı, üslü ifadeler konusunda yaşanan kavram yanılgılarının olası nedenleri ile bu kavram yanılgılarının önlenmesine yönelik neler yapılabileceğine dair ortaokul matematik öğretmeni adaylarının görüşlerini incelemektir. Bu amaç çerçevesinde “Üslü ifadelerde yaşanan kavram yanılgılarının olası nedenleri için ortaokul matematik öğretmen adaylarının görüşleri nelerdir?” ve “Üslü ifadelerde yaşanan kavram yanılgılarının önlenmesine yönelik ortaokul matematik öğretmen adaylarının görüşleri nelerdir? sorularına cevap aranmıştır.

\section{YÖNTEM}

Çalışmada nitel araştırma yaklaşımlarından durum çalışması yöntemi kullanılmıştır. Nitel araştırmalar bir konunun detaylı ve derinlemesine araştırılmasına olanak sağlamaktadır (Bogdan ve Biklen, 2007; Patton, 2002). Bu açıdan güncel bir olgunun kendi doğal ortamında detaylı araştırıldığı durum çalışması (Yin, 2003) bir nitel araştırma yöntemi olarak karşımıza çıkmaktadır. Bu bağlamda araştırmada, ilköğretim matematik öğretmeni adaylarının üslü ifadeler konusuna yönelik yaşanan kavram yanılgılarının olası neden ve önlemlerin derinlemesine incelenmesi amaçlandığı için nitel araştırma yaklaşımlarından durum çalışması yönteminin kullanılması uygun görülmüştür. 


\section{Çalışma Grubu}

Çalışmanın amacı öğretmen adaylarının üslü ifadeler ile ilgili literatürde karşılaşılan kavram yanılgılarının nedenleri ve önlem önerileri hakkında görüşlerini incelemektir. Bu amaç çerçevesinde özellikle son sınıf öğrencileri seçilmiştir. Çünkü öğretmen adayları tarafından bu aşamaya kadar konuyla ilgili olan (özel öğretim yöntemleri, hata kaynakları, matematiksel modelleme vb.) dersler alınmış ve en son yıl da okul deneyimi ve öğretmenlik uygulamasına geçilmiştir. Bu gibi derslerde örneğin hata kaynakları dersinde öğretmen adayları öğretim programında geçen konularla alakalı kavram yanılgılarının neler olabileceği üzerinde durmaktadırlar; özel öğretim yöntemleri dersinde matematikteki konuların nasıl daha iyi öğretilebileceği hakkında eğitimler verilmektedir. Bu açıdan bu derslerin önemli olduğu düşünülmektedir. Çalışma grubu Ankara ilinde bulunan bir Devlet üniversitesinde okuyan son sınıf ortaokul matematik öğretmeni adayları arasından seçilmiştir. Çalışma 2018-2019 eğitim-öğretim yılının bahar döneminde 29 öğretmen adayı ile gerçekleştirilmiş ve bunlardan gönüllü olan 9'u ile görüşmeler yapılmıştır. Araştırma grubu belirlenirken amaçlı örnekleme yöntemlerinden ölçüt örneklemesi kullanılmıştır. Ölçüt örnekleme ile araştırma grubu bir dizi ölçütü karşılama durumuna göre belirlenmektedir (Şimşek ve Yıldırım, 2016). Çalışmadaki ölçütler şu şekilde belirlenmiştir: İlki son sınıf öğrencileri olmaları, ikincisi öğretmen adaylarının özel öğretim yöntemleri, hata kaynakları, matematiksel modelleme vb. dersleri almış olmaları ve son olarak staj uygulamasına geçilmiş olunması. Katılımcılar gönüllülük esasına göre belirlenmiştir.

\section{Çalışmada Kullanılan Ölçme (Veri Toplama) Araçları}

Veriler alan yazında bulunan kavram yanılgılarından yararlanarak hazırlanmış olan görüşme(soru) formu üzerinden toplanmıştır. Görüşme (soru) formu hazırlanırken ortaokul matematik öğretim programındaki kazanımlar ve literatürdeki çeşitli çalışmalar dikkate alınmıştır. Kavram yanılgıları seçilirken Paksu (2008) tarafından ortaya koyulan kavram yanılgıları içerisinden ortaöğretim düzeyine uygun olan 8 tanesi seçilmiştir. Alan yazında karşılaşılan kavram yanılgıları araştırılmış, bu kavram yanılgıları ile neden ve önlem önerileri forma eklendikten sonra 5 uzmandan formun uygun olup olmadığına dair görüş alınmıştır. Uzman görüusünden sonra uygun düzeltmeler yapılmış ve görüşme formu en son haline getirilmiştir. Uzman görüş formunda seçilen 8 kavram yanılgısı nedenlerinin ve önlem önerilerinin bulunduğu bir tablo bulunmaktadır.

Aşağıda Şekil 1'de hazırlanan formdan bir örnek sunulmuştur.

Sizden beklenen üslü ifadeler ile ilgili aşağıda verilen kavram yanılgılarının olası nedenlerini ve önlem önerisi için düşüncelerinizi her bir sorunun yanındaki boşluğa yazıp açıklamanızdır.

\begin{tabular}{|c|c|c|}
\hline Kavram Yanılgisı & Olası Nedeni & Önlem Önerisi \\
$33^{2}=3 \times 2$ & & \\
\hline
\end{tabular}

Şekil 1. Üslü ifadeler veri toplama formundan örnek soru

Öğretmen adaylarına üslü ifadeler ile ilgili kavram yanılgılarının nedenleri ve önlem önerilerinin bulunduğu form uygulandıktan sonra görüşme için adayların seçiminde gönüllülük esas alınmıştır. Nitel araştırmaların özelliği gereği (Fraenkel ve Wallen, 2012) elde edilen veriler genelleme amacıyla değil fikir sunma amaçlı kullanılmıştır. Veri toplamak amacıyla alan yazında karşılaşılan kavram yanılgılarının nedenleri ve önlem önerileri hakkında öğretmen adaylarının görüşlerini incelemek için bir form hazırlanmıştır. Bu form 8 tane kavram yanılgısından oluşmaktadır. Paksu (2008)'in araştırmış olduğu çalışmada ortaya koyulan kavram yanılgıları içerisinden ortaöğretim düzeyine uygun olan 8 tane kavram yanılgısı seçilmiştir. Kavram yanılgılarının seçiminde ortaokul matematik öğretim programındaki kazanımlar dikkate alınmıştır. Bu nedenle kazanımlara yönelik literatürde geçen kavram yanılgıları seçilmiştir. Bu kavram yanılgılarına olası cevaplar; $3^{2}=3 \times 2,(-a)^{n}=-a^{n}, a^{0}=0, x^{3}=3 x, 3^{-2}=-9,2^{4} \times 5^{4}=(2 \times 5)^{4+4},\left(2^{3}\right)^{2}=2^{9}=512$ ve $2^{4}-2^{3}=2^{4-3}=2^{\prime}$ dir. 


\section{Veri Toplama Süreci}

Görüşme formu 29 öğretmen adayına bir ders saatinde iki araştırmacı tarafından uygulanmıştır. Daha sonra 29 kişiden gönüllülük esasına dayalı olarak 9 kişi ile görüşme formunda verdiğin cevaplar doğrultusunda görüşme yapılmıştır. Görüşmeyi araştırmacılar gerçekleştirmiştir. Görüşme sırasında katılımcıların ses kayıtları katılımcıların izni ile alınmıştır.

\section{Veri Analizi}

Öğretmen adayları ile yapılan görüşmelerden elde edilen ses kayıtları dinlenerek önce yazılı metne dönüştürülmüşs sonra nitel tekniklerle çözümlenmiştir. Öğretmen adaylarının üslü ifadeler ile ilgili kavram yanılgılarına dair neden ve görüşlerini belirttikleri formlar ve görüşmelerden elde edilen verilerden kod ve temalar belirlenmeye çalışılmıştır. Bunun için nitel analiz yaklaşımlarından "içerik analizi" tekniği kullanılmıştır. İçerik analizi yapılmasındaki amaç benzer verileri belirli kavram ve temalar çerçevesinde toparlamak ve bunları okuyucunun anlayabileceği şekilde düzenleyerek yorumlamaktır (Şimşek ve Yıldırım, 2016). Öğretmen adaylarının kavram yanılgılarının olası nedenlerine karşı yazdıkları verilerden temalar oluşturulurken Cornu (1991)'in oluşturduğu temalardan yararlanılmıştır. Olası nedenler pedagojik, epistemolojik ve psikolojik olmak üzere 3 temaya ayrılmıştır. Pedagojik teması “Öğretmenin derste kullandığı dil, Öğretmenin sadece bir örnek vermiş olması” gibi olası nedenlerin ortak teması olarak belirlenmiştir. Epistemolojik teması "Üslü ifadeler konusunun zorluğu” gibi olası nedenlerin teması olarak; Psikolojik teması ise "Öğrencinin bilgi eksikliği" gibi olası nedenlerin ortak teması olarak belirtilmiştir.

Olası neden ve önlem önerileri temaları oluşturulurken ise 3 bağımsız araştırmacı tarafından uzlaşı çalışması yapılmıştır. Her bir kavram yanılgısının önlem önerileri için “Tanıma odaklanma, konuyla ilgili örnekler verme, çoklu gösterim, materyalle somutlaştırma, alan kavramı ile ilişkilendirme, derse güdüleme, tek kuvvet ve çift kuvvet ile ilgili soru çözdürme, keşfettirme, parantezin işlevine dair ön bilgi, örüntü kullanımı, bölme algoritmasının kullanımı, kavramsal bilgi, taban ve üs kavramına vurgu, değerler konularak sağlama yapma, alan ve hacim ile ilişkilendirme, farklı yöntemlerle somutlaştırma, negatif ve pozitif üslerin karşılaştırılması, toplama ve çarpmada ters eleman vurgusu, konuyla ilgili sorular çözme, küçük sayıların yer aldığı sorular çözme, işlem adımlarına dikkat etme, işlemlere dair kavramsal bilgi, işlem önceliği vurgusu" temaları oluşturulmuştur. Örneğin öğretmen adaylarının yazdıkları “Üslü ifadelerdeki sayılar arasında örüntü kullanılarak verilen ifadeye ulaşılır” ve "Örüntüler yoluyla sayının sıfırıncı kuvvetinin 1'e eşit olduğu gösterilmelidir" önlem önerileri örüntü kullanımı teması altında toplanmıştır. "Öğretmenler daha küçük sayıların kullanıldığı örnekler vermelidirler” önlem önerisi konuyla ilgili örnekler verme teması altında kabul edilmiştir. “Öğretmen üslü ifadelerin sözel ifadesini anlatmalıdır, Öğretmen üslü ifadenin sayısal açılımını anlatmalıdır ve verilen ifadenin açılımı yazılmalıdır" önlem önerileri çoklu gösterim teması altında toplanmıştır.

\section{BULGULAR}

Araştırmanın bulguları, son sınıf öğretmen adaylarının alan yazında karşılaşılan kavram yanılgılarının nedenleri ve önlem önerileri hakkındaki görüşlerini incelemek amacıyla hazırlanan formdaki yanıtlardan ve yapılan görüşmelerden elde edilmiştir. Elde edilen bulgular alt problemler bazında incelenmiş ve ortak özellikleri çerçevesinde birleştirilerek tablolara yansıtılmıştır. Oluşturulan tabloda yer alan frekans değerleri öğretmen adaylarının görüşünü temsil etmektedir. Öğretmen adayları verdikleri yanıtlarda birden fazla neden ve önlem önerileri sunmuşlardır. Bazı öğretmen adayları ise neden ve önlem önerisi kısımlarını boş bırakmışlardır. Bu sebeplerden dolayı frekans toplamlarının çalışma grubunu oluşturan kişi sayısı olan 29' u vermesi beklenmemelidir. 
Üslü İfadelerde Yaşanan Kavram Yanılgılarının Olası Nedenleri ve Önlenmesine Yönelik Ortaokul Matematik Öğretmen Adaylarının Görüşleri

Bulgular öğretmen adaylarının düşündükleri olası nedenler ve bu kavram yanılgısının önlenmesine yönelik düşüncelerinin bulunduğu tablolar şeklinde sunulmuştur. Aşağıda verilen ilk tablo öğretmen adaylarının formdaki 1. kavram yanılgısı olan " $3^{2}=3 \times 2$ " ile ilgili olası nedenler ve önlem önerileri hakkındaki görüşleri incelenip temalar oluşturularak hazırlanmıştır.

Tablo 1. Öğretmen Adaylarının 3²=3x2 Kavram Yanılgısının Nedenlerine ve Önlenmesine Yönelik Verdikleri Yanitların Frekans Tablosu

\begin{tabular}{llcc}
\hline & $3^{2}=3 \times 2$ kavram yanılgısı & Frekans(f) & Yüzde (\%) \\
\cline { 2 - 4 } Olası Nedeni & Psikolojik & 15 & 57,7 \\
& Pedagojik & 10 & 38,5 \\
& Epistemolojik & 1 & 3,8 \\
& Toplam & Tanima odaklanma & 100 \\
\hline \multirow{3}{*}{ Önlem Önerisi } & Konuyla ilgili örnekler verme & 26 & 26,7 \\
& Çoklu gösterim & 7 & 23,3 \\
& Materyalle somutlaştırma & 7 & 23,3 \\
& Alan kavramı ile İlişkilendirme & 5 & 16,7 \\
& Derse güdüleme & 2 & 6,7 \\
& Toplam & 1 & 3,3 \\
\hline
\end{tabular}

Tablo 1 incelendiğinde öğretmen adayları " $32=3$ x 2" kavram yanılgısının olası nedenlerine ve önlem önerisi olarak verdikleri cevaplar bulunmaktadır. Olası nedenler olarak en çok psikolojik nedenler belirtilmiştir (\%57,7). Bu nedenlere bakıldığında öğrencinin bilgi eksikliği üzerine yoğunlaşttğg görülmüştür. Bunu takiben \%38,5 ile pedagojik nedenler gelmektedir. Belirtilen nedenlerden üslü ifadeler konusunun zorluğu epistemolojik neden olarak sadece bir öğretmen adayı tarafından belirtilmiştir. Görüşmeler incelendiğinde öğretmen adaylarının forma yazdıkları nedenlere ek olarak kavram yanılgısının oluşma nedeninin öğretmenden de kaynaklı yani pedagojik olabileceğini söylemişlerdir. Görüşmede verilen cevaplar içerisinde en çok doğal sayılardaki çarpmaya genelleme nedenini söylemişlerdir. Önlem önerisi olarak en çok (\%26,7) üslü ifadenin tanımına odaklanması gerektiği şeklinde bir ifade yazılmıştır. Verilen yanıtlar arasında bu ifadeye ek örnekler üzerinden anlatılmalıdır önlem önerisi $(23,3)$ ve üslü ifadelerin çoklu gösterimlerinin verilmesi önlem önerisi $(23,3)$ yazılmıştır. Ayrıca bir öğretmen adayı derse güdüleme anlamında derse dikkat çekerek başlanmalıdır ifadesini öneri olarak belirtmiştir. Tablo 2'de Öğretmen adaylarının formdaki 2. kavram yanılgısı olan $(-a)^{\mathrm{n}}=-\mathrm{a}^{\mathrm{n}}$ ifadesine yönelik olası nedenleri ve önlenmesine yönelik görüşleri incelenip temalar oluşturularak hazırlanmıştır.

Tablo 2. Öğretmen Adaylarının $(-\mathrm{a})^{\mathrm{n}}=-\mathrm{a}^{\mathrm{n}}$ Kavram Yanılgısının Nedenlerine ve Önlenmesine Yönelik Verdikleri Yanıtların Frekans Tablosu

\begin{tabular}{llcc}
\hline & $(-\mathrm{a})^{\mathrm{n}}=-\mathrm{a}^{\mathrm{n}}$ kavram yanılgısı & Frekans (f) & Yüzde (\%) \\
\cline { 2 - 4 } Olası Nedeni & Psikolojik & 19 & 65,5 \\
& Pedagojik & 10 & 34,5 \\
& Epistemolojik & 0 & 0 \\
& Toplam & 29 & 100 \\
\hline \multirow{3}{*}{ Önlem Önerisi } & Tek kuvvet ve çift kuvvet ile ilgili soru çözdürme & 9 & 36 \\
& Keşfettirme & 7 & 28 \\
& Çoklu gösterim & 7 & 28 \\
& Parantezin işlevine dair ön bilgi & 2 & 8 \\
& Toplam & 25 & 100 \\
\hline
\end{tabular}

Tablo 2 incelendiğinde öğretmen adayları “(-a $)^{\mathrm{n}}=-\mathrm{a}^{\mathrm{n} \text { ” }}$ kavram yanılgısının olası nedeni olarak en çok öğrencinin parantezin anlamını ve işlevini bilmemesi gibi psikolojik nedenler belirtmişlerdir (\%65,5). Verilen yanıtlar arasında öğretmenin derste kullandığı dil (pedagojik) dikkat çeken nedenler arasında bulunmaktadır. Öğretmenin kullandığı dilin neden olarak gösterilmesi kavram yanılgısının öğretmen kaynaklı olabileceğinin düşünüldüğünü 
göstermektedir. Öte yandan öğretmen adayları önlem önerisi olarak en çok (\%36) öğretmenin üssün tek olma ve çift olma durumlarını açıklaması ve bol örnek çözülmelidir ifadesini belirtmişlerdir. Verilen cevaplarda zıt örnekler vererek öğrencinin doğruyu kendi keşfetmesi sağlatılabilir ve konu anlatılırken çoklu gösterimler kullanılması gerekir ifadeleri önlem önerisi olarak sunulmuştur. Öğretmen adayları en az parantezin işlevine dair ön bilgi üzerinde durulması gerektiği ifadelerini öneri olarak belirtmişlerdir. Adayların olası nedenler olarak sunulan kısımlara yönelik önlem önerileri verdikleri görülmektedir. Tablo 3 Öğretmen adaylarının formdaki 3. kavram yanılgısı olan $\mathrm{a}^{0}=0$ ifadesinin olası nedenlerine ve önlenmesine yönelik görüşleri incelenerek hazırlanmıştır.

Tablo 3. Öğretmen Adaylarının $\mathrm{a}^{0}=0$ Kavram Yanılgısının Nedenlerine ve Önlenmesine Yönelik Verdikleri Yanitların Frekans Tablosu

\begin{tabular}{llcc}
\hline & $\mathrm{a}^{0}=0$ kavram yanılgısı & Frekans (f) & Yüzde (\%) \\
\cline { 2 - 4 } Olası Nedeni & Pedagojik & 12 & 46,2 \\
& Psikolojik & 9 & 34,6 \\
& Epistemolojik & 5 & 19,2 \\
& Toplam & 26 & 38,5 \\
\hline \multirow{3}{*}{ Önlem Önerisi } & Örüntü kullanımı & 10 & 30,8 \\
& Öneri yok & 8 & 23,1 \\
& Bölme algoritmasının kullanımı & 6 & 3,8 \\
& Çoklu gösterim & 1 & 3,8 \\
& Kavramsal bilgi & 1 & 100 \\
& Toplam & 26 & 100 \\
\hline
\end{tabular}

Tablo 3 incelendiğinde öğretmen adayları " $\mathrm{a}^{0}=0$ " kavram yanılgısının olası nedeni olarak en fazla pedagojik nedenleri belirttikleri görülür $(\% 46,2)$. Bunu takiben verilen yanttlar olası nedenlerin psikolojik olabileceği $(\% 34,6)$ ile epistemolojik nedenlerden kaynaklı olabileceğinin belirtildiği görülmüştür. Bu kavram yanılgısının yaşanmasını önlemeye yönelik verilen önlem önerilerinin en fazla örüntü kullanımı $(\% 38,5)$ ile sayının sıfırıncı kuvvetinin 1'e eşit olduğunun gösterilmesi gerektiği ifade edilmiştir. Önerilere yönelik verilen cevaplar arasında nasıl düzeltileceğini bilmiyorum $(\% 30,8)$ ifadesinin kullanılması dikkat çekicidir. Önlem olarak istenen durum bu kavram yanılgısının yaşanmaması adına alınabilecek tedbirler olmasına karşın burada öğretmen adaylarının düzeltme olarak algıladıkları görülmektedir. Bir diğer öneri ise üslü ifadelerde bölme algoritmasını kullanarak sayının sıfırıncı kuvvetinin 1'e eşit olduğunun gösterilmesi olarak belirtilmiştir. Öğretmen adayları en az çoklu gösterim ve üslü ifadeler ile ilgili temel kavramların (üs, taban) üzerinde durulmalıdır yani kavramsal bilgi önerilerini belirtmişlerdir. Tablo 4'te matematik öğretmen adaylarının formdaki 4 . kavram yanılgısı olan $x^{3}=3 \times$ ifadesinin olası nedenlerine ve önlenmesine yönelik görüşleri incelenerek oluşturulan temalar sunulmuştur.

Tablo 4. Öğretmen Adaylarının $x^{3}=3^{x}$ Kavram Yanılgısının Nedenlerine ve Önlenmesine Yönelik Verdikleri Yanitların Frekans Tablosu

\begin{tabular}{llcc}
\hline & $\mathrm{x}^{3}=3 \times$ & Frekans (f) & Yüzde (\%) \\
\cline { 2 - 4 } Olası Nedeni & Pedagojik & 13 & 50 \\
& Psikolojik & 13 & 50 \\
& Epistemolojik & - & - \\
& Toplam & 26 & 100 \\
\hline \multirow{3}{*}{ Önlem Önerisi } & Çoklu gösterim & 15 & 60 \\
& Taban ve üs kavramina vurgu & 6 & 24 \\
& Değerler konularak sağlama yapma & 2 & 8 \\
& Alan ve hacim ile ilişkilendirme & 1 & 4 \\
& Farklı yöntemlerle somutlaştırma & 1 & 4 \\
& Toplam & 25 & 100 \\
\hline
\end{tabular}

Yukarıda verilen tablo incelendiğinde öğretmen adayları " $\mathrm{x}^{3}=3^{x "}$ kavram yanılgısının olası nedeni olarak $\% 50$ pedagojik nedenler olurken diğer \%50 ise psikolojik nedenler olarak yoğunlaştığı görülmektedir. Verilen yanıtlar arasında öğrencinin üslü ifadelerdeki üs ve tabanın neyi ifade ettiğini bilmemesi nedeni ve öğrencinin üslü ifadenin sayısal olarak açlımını bilmemesi de dikkat çeken ifadelerdir. Bu durumda öğrencinin kavrama yönelik temel 
bilgilerindeki eksikliklerin (psikolojik) kavram yanılgısına neden olabileceği düşünülmektedir. Öğretmen adayları pedagojik neden olarak öğretmenin konu anlatımında sadece bir örnek vermiş olmasının da olası nedenler arasında olabileceğini belirtmişlerdir. Bu kavram yanılgısının önlenmesine yönelik verilen önlem önerisi ise öğretmenin üslü ifadelerin çoklu gösteriminden yararlanması gerektiği şeklinde ifade edilmiştir (\%60). Verilen öneriler içinde üslü ifadelerdeki taban ve üssün anlamı üzerinde durulması gerektiği de belirtilmiştir. Öğretmen adayları en az x yerine 2 konularak iki ifadenin hacim ve alan kavramlarından yola çıkarak anlatılması ve konuya yönelik karikatürler kullanılarak kalıcılığın sağlanması gerektiğini öneri olarak belirtmişlerdir.

Tablo 5. Öğretmen Adaylarının $3^{-2}=-9$ Kavram Yanılgısının Nedenlerine ve Önlenmesine Yönelik Verdikleri Yanitların Frekans Tablosu

\begin{tabular}{llcc}
\hline & $3^{-2}=-9$ kavram yanılgısı & Frekans & Yüzde (\%) \\
\cline { 2 - 3 } Olası Nedeni & Pedagojik & 9 & 32,1 \\
& Psikolojik & 7 & 25 \\
& Epistemolojik & 12 & 42,9 \\
& Toplam & 28 & 100 \\
\hline & Örüntü kullanma & 6 & 26,1 \\
Önlem Önerisi & Çoklu gösterim & 6 & 26,1 \\
& Bölme algoritması & 3 & 13,1 \\
& Toplama ve çarpmada ters eleman vurgusu & 3 & 13,1 \\
& Farklı yöntemlerle somutlaştırma & 2 & 8,7 \\
& Taban ve üs kavramına vurgu & 1 & 1 \\
& Konuyla ilgili sorular çözme & 1 & 4,3 \\
& Toplam & 1 & 4,3 \\
\end{tabular}

Tablo 5 incelendiğinde öğretmen adaylarının "3-2=-9" kavram yanılgısıyla ilgili olarak yazdıkları olası nedenlerin en çok 12'sinin (\%42,9'unun) epistemolojik teması altında toplandığı görülmektedir. Olası nedenlerin 9'unun (\%32,1'inin) pedagojik nedenli; 7 'sinin (\%25'inin) psikolojik nedenlerden kaynaklandiğı tabloda sunulmuştur. Önlem önerilerinin 6'sının (\%26,1'inin) örüntü kullanma ve negatif ve pozitif üslerin karşılaştırılması teması altında; 3'ünün (\%13,1'inin) çoklu gösterim ve bölme algoritması; 2'sinin (\%8,7'sinin) toplamada ve çarpmada ters eleman vurgusu temaları altında toplandığı görülmektedir. Öğretmen adayları örüntü kullanma teması altında "üslü ifadelerdeki sayılar arasında örüntü kullanılarak verilen ifadeye ulaşılır" gibi önlem önerileri yazmışlardır.

Tablo 6. Öğretmen Adaylarının $2^{4} \times 5^{4}=(2 \times 5)^{4+4}$ Kavram Yanılgısının Nedenlerine ve Önlenmesine Yönelik Verdikleri Yanitların Frekans Tablosu

\begin{tabular}{llcc}
\hline & $2^{4} \times 5^{4}=(2 \times 5)^{4+4}$ kavram yanılgısı & Frekans & Yüzde $(\%)$ \\
\cline { 2 - 4 } Olası Nedeni & Pedagojik & 24 & 96 \\
& Psikolojik & 1 & 4 \\
& Epistemolojik & - & - \\
& Toplam & 25 & 100 \\
\hline \multirow{3}{*}{ Önlem Önerisi } & Foklu gösterim & 2 & 13,3 \\
& Tarklı yöntemler somutlaştırma & 1 & 6,7 \\
& Kavramsal öğrenme & 2 & 13,3 \\
& Küçük sayıların yer aldı̆̆ı sorular çözme & 3 & 20 \\
& Konuyla ilgili sorular çözme & 4 & 26,7 \\
& Konuyla ilgili örnekler verme & 2 & 1 \\
& Toplam & 15,3 & 6,7 \\
\hline
\end{tabular}

Tablo 6 incelendiğinde öğretmen adaylarının " $2^{4} \times 5^{4}=(2 \times 5)^{4+4^{\prime \prime}}$ kavram yanılgısıyla ilgili olarak yazdıkları olası nedenlerin 24'ünün (\%96'sının) pedagojik teması altında toplandığı görülmektedir. Kavram yanılgısı ile ilgili olası nedenlerin 1'inin (\%4'ünün) psikolojik nedenli olduğu bulunmuştur. Kavram yanılgısına karşı önlem önerilerinin 4'ünün (\%26,7'sinin) "küçük sayıların yer aldığı sorular çözme” teması altında; 3’ünün (\%20'sinin) kavramsal öğrenme temaları altında toplandığı tespit edilmiştir. Öğretmen adayları küçük sayıların yer aldığı sorular çözme 
teması altında "öğretmenler daha küçük sayıların kullanıldığı örnekler vermelidirler"; kavramsal Öğrenme teması altında "üslü ifadelerde taban ve üs kavramlarının üzerinde durulmalıdır" gibi önlem önerileri yazmışlardır.

Tablo 7. Öğretmen Adaylarının $\left(2^{3}\right)^{2}=2^{9}=512$ Kavram Yanılgısının Nedenlerine ve Önlenmesine Yönelik Verdikleri Yanitların Frekans Tablosu

\begin{tabular}{llcc}
\hline & $\left(2^{3) 2}=2^{9}=512\right.$ kavram yanılgisı & Frekans & Yüzde (\%) \\
\cline { 2 - 3 } Olası Nedeni & Pedagojik & 13 & 68,42 \\
& Psikolojik & 5 & 26,32 \\
& Epistemolojik & 1 & 5,26 \\
& Toplam & 19 & 100 \\
\hline \multirow{3}{*}{ Önlem Öneklu gösterim } & 11 & 47,8 \\
& İslem adımlarına dikkat etme & 3 & 13,0 \\
& Küçük sayılardan örnekler verme & 2 & 8,7 \\
& Taban ve üs kavramı & 2 & 8,7 \\
& Tanim bilgisi & 1 & 4,4 \\
& Keşfettirme & 4 & 17,4 \\
& Toplam & 23 & 100 \\
\hline
\end{tabular}

Tablo 7 incelendiğinde öğretmen adaylarının “ $\left(2^{32}\right)=2^{9}=512$ " kavram yanılgısıyla ilgili olarak yazdıkları olası nedenlerin en çok 13'ünün (\%68,42'sinin) pedagojik teması altında toplandığı görülmektedir. Kavram yanılgisı ile ilgili olası nedenlerin 5'inin (\%26,32'sinin) psikolojik nedenli; $1^{\prime}$ inin $(\% 5,26$ 'sının) epistemolojik nedenlerden kaynaklandığı bulunmuştur. Kavram yanılgısına karşı önlem önerilerinin 11'inin (\%47,8'nin) çoklu gösterim teması altında; 4'ünün (\%17,4'ünün) keşfettirme; 3'ünün (\%13'ünün) işlem adımlarına dikkat etme; 2'sinin (\%8,7'sinin) küçük sayılardan örnekler verme ve taban ve üs kavramı temaları altında toplandığı görülmektedir. Öğretmen adayları çoklu gösterim teması altında "konunun başında ifadenin sayısal olarak açılımı yapılmalıdır"; keşfettirme teması altında "çelişki durumu oluşacak örnekler verilmelidir" gibi önlem önerileri yazmışlardır.

Tablo 8. Öğretmen Adaylarının $2^{4}-2^{3}=2^{4-3}=2$ Kavram Yanılgısının Nedenlerine ve Önlenmesine Yönelik Verdikleri Yantların Frekans ve Yüzde Tablosu

\begin{tabular}{llcc}
\hline & $2^{4}-2^{3}=2^{4-3}=2$ kavram yanılgisı & Frekans & Yüzde (\%) \\
\cline { 2 - 4 } Olası Nedeni & Pedagojik & 24 & 96 \\
& Psikolojik & 1 & 4 \\
& Epistemolojik & - & - \\
& Toplam & 25 & 100 \\
\hline \multirow{3}{*}{ Önlem Öneklu gösterim } & 14 & 58,3 \\
& İşlemlere dair kavramsal bilgi & 4 & 16,7 \\
& Konuyla ilgili örnekler verme & 3 & 12,5 \\
& İşlem önceliği vurgusu & 3 & 12,5 \\
& Toplam & 24 & 100 \\
\hline
\end{tabular}

Tablo 8 incelendiğinde öğretmen adaylarının “ $2^{4-23}=2^{4-3}=2^{\prime \prime}$ kavram yanılgısıyla ilgili olarak yazdıkları olası nedenlerin çoğunluğu pedagojik teması altında toplanmıştır. Pedagojik temasının yazılan olası nedenlerinin \%96'sını oluşturduğu tespit edilmiştir. Elde edilen verilerin \%4'ünün ise psikolojik nedenlerden kaynaklandığı ifade edilmiştir. Önlem önerisi için bakıldığında çoklu gösterim temasının genel önlem önerilerinin 14 'ünü (\%60,87'sini) oluşturduğu görülmektedir. Çoklu gösterim temasında öğretmen adayları konunun başında ifadenin sayısal olarak açılımı yapılmalıdır gibi önlem önerileri belirttikleri tespit edilmiştir. Öğretmen adaylarının önlem önerileri için yazdıkları verilerden oluşturulan “işlemlere dair kavramsal bilgi” teması önlem önerilerinin 4'ünü (\%17,39'unu); “Konuyla ilgili örnekler verme" teması 3'ünü (\%13,04'ünü); “İşlem önceliği vurgusu” teması ise önlem önerilerinin 3’ünü (\%13,04'ünü) oluşturmaktadır. Özellikle konunun kavramsal öğretimi üzerinde durulması da bir diğer vurgulanan kısım olarak görülmektedir.

Genel olarak kavram yanılgılarının önlenmesine yönelik olarak öğretmen adayları, öğretmenin konunun başında üslü ifadenin sayısal açılımının üzerinde durması, üslü ifadelerdeki taban ve üssün anlamı üzerinde durulması, üslü ifadelerin sözel ifadesini anlatılması ve üslü ifadelerdeki kavramların anlamlarının tekrar edilmesi 
gerektiğini belirtmişlerdir. Örüntüler yoluyla sayının sıfırıncı kuvvetinin 1'e eşit olduğunun gösterilmesi, üslü ifadelerdeki sayılar arasında örüntü kullanılarak verilen ifadeye ulaşılması, konunun öğretiminde birim küplerle etkinlik yapılması ve üslü ifadeler konusuna girişte karenin alanı ve çevresi üzerinden giderek konunun anlatılması önerilmiştir. Üslü ifadelerde bölme işlemini kullanarak sayının sıfırıncı kuvvetinin 1'e eşit olduğunun gösterilmesi, ifadeye üslü ifadelerdeki bölme işlemini kullanarak ulaşılmasının sağlanması gerektiği de belirtilmiştir. Konu anlatımında farklı örnekler verme, konunun başında bol örnek verilmesi, çelişki durumu oluşacak örnekler verilmesi ve verilen ifadenin zıt örneklerle karşılaştırılması böylece öğrencinin doğruyu kendi kendine keşfetmesinin sağlatılması gerektiği belirtilmiştir. İşlem önceliğinin vurgulanması, parantezin anlamını ve işlevi üzerinde durulması gerektiği de belirtilmiştir. Verilen işlemin adımlarının tek tek yapılması gerektiği ve daha küçük sayılardan oluşan örnekler verilmesi önerilmiştir. Üslü ifadelerde bölme işlemi ile üslü ifadelerdeki çlkarma işlemi arasındaki farkın vurgulanması gerektiği, konunun başında iki kuralın da farklı durumlarda kullanıldığının gösterilmesi ve kavratılması gerektiği de ifade edilmiştir. Üslü ifadenin üssünün "-" nin sayıyı kesre dönüştüreceği üzerinde durulması ve bir sayının çarpma işlemine göre tersi ve toplama işlemine göre tersi kavramlarının sınıfta tartışılması, öğretmenin üssün tek olma ve çift olma durumlarını açıklaması ve bol örnek çözülmesi de öneriler arasındadır. Görüşmelerde bazı konuları etkinlikler üzerinden anlatmasının önemli olduğu ifade edilmiştir. Aşağıda öğretmen adayının görüşmelerde anlattığı örnek etkinlik verilmiştir;

“Sınıfta biz bir etkinlik yapmışıı. Özel öğretim yöntemleri dersinde geçen sene üslü sayıları anlatırken orda A4 kâğıtları ile katlama yaparak göstermiştik. Mesela 2'nin kuvvetlerini yazarken ilkönce bir kez 2'ye katladım sonra tekrar 2 kez 2'ye katladım 4 bölgeye ayrıldı. 3 kez 2'ye katladım kâ̆ğıt 8 bölgeye ayrıldı bu şekilde bir genellemeye gitmiş̧tik. Yine ben bu formülleri de bunun üzerinden verebileceğimizi düşündüm. 2 tane A4 kâ̆̆ıdı var elimde diyelim ki bir tane A4 kâğıdını n kez katladı̆̆ımda kaç bölge oluşuyor diğerini $m$ kez katladığımda kaç bölge oluşuyor. Ondan sonra bir de n+m kez 2' ye katlayarak gittiğimde onların çarpımı kadar sayıda mı bölge oluşuyor bunu görmelerini sağlayıp formüle gitmelerini düşündüm."

Görüldüğü gibi öğretmen adayı öğrencinin formüle ulaşmasının sağlanması gerektiğini düşünmektedir.

\section{SONUÇ, TARTIŞMA ve ÖNERİLER}

Ortaokul matematik öğretmen adaylarının öğrencilerin üslü ifadeler ile ilgili sahip oldukları kavram yanılgılarının olası nedenleri ve bunların oluşmaması için öğretime yönelik ne gibi önlemler alınabileceğine yönelik görüşlerini araştırmak için yapılan bu çalışmada ilk olarak olası nedenler incelenmiştir. Bu nedenler üç başlık altında toplanmıştır. Bunlar; Pedagojik nedenler, psikolojik nedenler ve epistemolojik nedenler olarak sıralanmıştır. Psikolojik nedenlere bakıldığında, öğrencinin bilgi eksikliğinin, üslü ifadelerdeki üs ve tabanın neyi ifade ettiğinin bilinmemesi, üslü ifadenin sayısal olarak açılımının bilinmemesi, öğrencinin parantezin anlamını ve işlevini bilmemesi, üssün tek ve çift olma durumundaki kuralın bilinmemesi ve negatif üssün anlamının kavranamamasının kavram yanılgılarına neden olabileceği belirtilmiştir. Alan yazında öğrencilerin üslü ifadelerde kullanılan matematiksel dili anlama ve kullanma seviyelerinin orta seviyede olduğu ve matematiksel dil kullanım düzeyiyle matematik başarıları arasında pozitif bir ilişki olduğu tespit edilmiştir (Güzel ve Yılmaz, 2020). Pedagojik nedenler ise öğretmenin anlatımından kaynaklı olarak öğrencilerin doğal sayılardaki çarpmaya genelleme yapması, üslü ifadelerdeki bölme işlemi kuralının üslü ifadelerdeki çıkarma işlemine genellemesi, üslü ifadelerdeki çarpma işlemindeki kuralın da çıkarma işlemine genellemesi, öğrencilerin çarpma işlemindeki çarpanların yer değiştirmesini (değişme özelliği) üslü ifadelere genellemesinin olası nedenler arasında olabileceği ifade edilmiştir. Benzer şekilde üslü ifadelerde çarpma işleminde tabanları aynı olan üslü ifadelerin tabanları aynı olan üsler toplanır kuralına genellemesi, üslü ifadelerde çarpma işleminde tabanları aynı olan üslü ifadelerin üslerin toplanması kuralı ile üsler aynı olduğunda tabanlar çarpılır kuralının birleştirilmesi ve genellemesi, çarpma işlemindeki negatif sayı ile pozitif sayı çarpılırsa negatif olur kuralının üslü ifadelere genellemesi, çarpma işlemindeki sıfırın yutan eleman özelliğinin üslü ifadelerdeki bu ifadeye genellemesi ve öğrencinin sayının kuvvetini çarpma işlemi gibi düşünmüş olmasının da olası nedenler arasında sayılabileceği ifade edilmiştir. Bununla birlikte epistemolojik nedenler için üslü ifadelerin 
açılımının kavramsal öğreniminden kaynaklı olması muhtemel nedenler arasında belirtilmiştir. Nitekim alan yazında da öğrencilerin üslü ifadelerdeki birçok kuralı aşırı genellemelerinin de üslü ifadelerde bilgi eksikliğinden kaynaklanmakta olduğu belirlenmiştir (Aydın, 2011; Cengiz, 2006; Özkaya, vd, 2013). Öğretmen adaylarına form uygulandıktan sonra yapılan görüşmelerde formda yazdıklarına ek olarak kavram yanılgılarının nedenleri olarak öğretmenin kullandığı dilinde etkili olabileceğini belirtmişlerdir. Bu durum öğretmen adaylarının belirttikleri olası nedenlerin alan yazınla desteklendiğini göstermektedir. Nitekim Özkaya, Konyalığlu ve Gedik (2013) yaptıkları çalışmada matematik öğretmeni adaylarının üslü ve köklü ifadelerde öğrencilerin sahip olabilecekleri hatalara yaklaşımlarını incelemişlerdir. Bu amaç için matematik öğretmeni adaylarına hataların oluşma sebeplerini tespit etmeye yönelik cevabı verilen sorular ile açık uçlu bir soru sorulmuştur. Ayrıca bu hatalar hakkındaki görüşlerini ve çözüm önerilerini belirlemeye çalışmışlardır. Çalışmanın sonucunda öğretmen adaylarının matematik alan bilgisindeki eksiklikleri nedeniyle hataları açıklamada sıkıntı yaşadıkları görülmüştür. Öğretmen adayları kavram yanılgılarının oluşmasında öğrenci ve öğretmen olarak iki kaynak üzerinde durmuşlardır. Bu durum çalışmamızdaki psikolojik ve pedagojik olası nedenlerin alan yazınla desteklendiğini göstermektedir. Çözüm önerisi olarak kavramsal öğrenme, görsel materyal kullanımı, farklı ve benzer örnek verme şeklinde öneriler verilmiştir. Çalışmamızda kavram yanılgılarının önlenmesine yönelik bulgulara bakıldı̆̆ında ilk göze çarpan durum öğretmen adaylarının önlem önerisini çözüm önerisi olarak düşünmüş olmalarıdır. Bu durum görüşmelerde ortaya çıkmıştır. Ayrıca öğretmen adayları bazı kavram yanılgıları ile ilgili önlem önerilerini boş bırakmışlar ya da nasıl bir önlem alınacağını bilmediklerini belirtmişlerdir. Bu durum bazı öğretmen adaylarının pedagojik alan bilgisinde eksikler olduğunu göstermektedir. Özkaya ve diğerlerinin çalışmasında da benzer sonuca rastlanmıştır.

Alan yazındaki çalışmalara bakıldığında da üslü ifadeler konusunun etkinlik temelli işlendiğinde çocukların akademik başarısına olumlu katkıları olduğu belirlenmiştir (Aslan, 2018; Bilgin ve Dinç, 2015; Saraç, 2016; Sastre ve Mullet, 1998). Saraç (2016) çalışmasında öğrencilerin zorlandıkları konulardan biri olan üslü ifadelerin öğretiminde kullanılabilecek iki benzetim örneğini tanıtmıştır. Bu çalışmada üslü ifadeler konusunda en sık karşılaşılan kavram yanılgılarından taban ve kuvveti ifade eden sayıları çarpma ve pozitif ve negatif sayıların tek ve çift kuvvetlerinin işaretlerinin belirlenmesi durumlarına yönelik olarak çamurlu ayakkabılar ve doktor-hasta ilişkisi isimli iki benzetim tasarlanmıştır. Çalışmanın sonucunda öğrencilerin kavram yanılgılarına düşme oranının azaldığı fark edilmiştir. Bilgin ve Dinç (2015) de çalışmasında buluş ve geleneksel yöntemlerle üslü ifadeler konusu işlenip, soru çözdürtmenin mezun öğrencilerin öğrenme düzeyine ve problem çözmedeki becerileri üzerine etkileri incelemiştir. Araştırmanın sonucunda deney grubunun puanlarının kontrol grubuna göre daha yüksek olduğu bulunmuştur.

Alan yazındaki uygulamalı çalışmalar incelendiğinde öğrencilere bir konunun kural veya formül şeklinde değil, öğrencilerin kendilerinin kavramı keşfetmelerine olanak sağlayacak ortamlar ve etkinlikler ile öğretimin yapılması önerilmektedir. Öğretmen adaylarının verdiği önlem önerilerinde tanımların üzerinde durulması ve kavram bilgisinin önemini vurgulanmaktadır. Alan yazında da üslü ifadelerin ne anlama geldiğinin tanıtılması, bunların nasıl, nerede kullanılacağını içeren etkinlikler ile ders tasarlamanın önemli katkı sağladığı görülmektedir (Argün, vd., 2014). Kavram yanılgılarına dair öğretmen adaylarının belirttikleri olası neden ve önlem önerilerine bakıldığında matematik öğretmeni adaylarının gerekli pedagojik bilgiye sahip olduğu görülmektedir. Bu durum eğitim fakültelerinde bu konuya yönelik derslerin sonucu olabilmektedir. Nitekim öğretmen adayları görüşmelerde derste gördükleri durumlar üzerinden açıklamalar yazdıklarını belirtmişlerdir. Öte yandan verilen önlem önerilerinin çoğunlukla pedagojik nedenlere yönelik olduğu, psikolojik nedenlere yönelik önlem önerisi sunulmadığı görülmüştür.

Çalışmanın sonuçlarından yola çıkarak, bundan sonraki çalışmalarda üslü ifadelerdeki alan yazında rastlanan kavram yanılgılarının nedenleri ve önlem önerileri ile ilgili olarak deneyimli olan ilköğretim matematik öğretmenleri ile görüşmeler yapılabilir. Sahada deneyime sahip öğretmenler burada matematik öğretmeni adayları tarafından verilen önerileri uygulamış olma olasılığına sahip kişiler olduğu için deneyimlerine dayanarak daha sağlam öneriler sunabilirler. Üslü ifadelerdeki alan yazında rastlanan kavram yanılgılarının nedenleri ve önlem önerileri ile ilgili olarak ilköğretim matematik öğretmenleri ve öğrencilerle ile ayrı ayrı görüşme yapılıp iki ayrı grubun görüşleri 
karşılaştırılarak incelenebilir. Böyle bir çalışma olası nedenleri tespit etme adına alan yazına fayda sağlayabilir. Bu çalışma matematik öğretmeni adaylarının üslü ifadeler ile ilgili hazırlayacakları ve uygulayacakları ders planları üzerinden mikro öğretim tarzında uygulamalarla yapılabilir. Bu tarz yapılacak bir çalışma ile verilen önerilerin uygulanabilirliği ve işlevi hakkında fikir sahibi olunabilir. 
KAYNAKÇA

Argün, Z., Arıkan, A., Bulut, S., \& Halıcıŏlu, S. (2014). Temel matematik kavramların künyesi. Ankara: Gazi Kitapevi.

Aslan, N. (2018). Üslü ifadelerle etkinlik temelli öğretimin matematik akademik başarısına, tutumuna ve kaygı-endişe düzeyine etkisi. (Yayınlanmamış Yüksek Lisans Tezi). Balıkesir Üniversitesi Fen Bilimleri Enstitüsü.

Aydın, A. (2011). Fen bilgisi öğretmenliği öğrencilerinin bazı matematik kavramlarına yönelik hatalarının ve bilgi eksiklerinin tespit edilmesi. Balıkesir Üniversitesi Fen Bilimleri Enstitüsü Dergisi, 13(1), 78-87.

Bayram, G., \& Duatepe-Paksu, A. (2015). 8. sınıf öğrencilerinin üslü ifadelere ilişkin sayı duyuları ve başarıları arasındaki ilişki. Batı Anadolu Ĕ̆itim Bilimleri Dergisi, 5(9), 47-70.

Beeth, M. E., \& Adadan, E. (2006). The influences of university-based coursework on field experience. Journal of Science Teacher Education, 17(2), 103-120.

Bilgin, T. \& Dinç, Y. (2015). Buluş yöntemi ile öğretimin üslü sayılar konusunu öğrenme düzeyine ve erişiye etkileri. Abant İzzet Baysal Üniversitesi Eğitim Fakültesi Dergisi, 3(2), 125-139.

Bingölbali, E., \& Özmantar, M.F. (2012). İlköğretimde karşılaşılan matematiksel zorluklar ve çözüm önerileri (3. Baskı). Ankara: Pegem Akademi.

Bogdan, R. C., \& Biklen, S. K. (2007). Research for education: An introduction to theories and methods. Boston: Allyn and Bacon.

Cengiz, Ö. M. (2006). Reel sayıların öğretiminde bir kısım ortaöğretim öğrencilerinin yanılgılar ve yanlışları üzerine bir çalışma. (Yayımlanmamış Yüksek Lisans Tezi). Atatürk Üniversitesi Sosyal Bilimler Enstitüsü, Erzurum.

Christou, C., Pantazi, D. \& Zachariades, T. (2007). Secondary school students' levels of understanding in computing exponents. Journal of Mathematical Behavior, 26, 301-311.

Cornu, B. (1991). Limits. In D. Tall (Ed.), Advanced mathematical thinking. Boston: Kluwer.

Erdem, Z. (2013). Öğrencilerin denklem konusundaki hata ve kavram yanılgılarının belirlenmesi ve bu hata ve yanılgılarmn nedenleri ve giderilmesine ilişkin öğretmen görü̧̧leri. (Yayımlanmamış Yüksek Lisans Tezi). Adıyaman Üniversitesi Fen Bilimleri Enstitüsü, Adıyaman.

Fraenkel, J. R., \& Wallen, N. E. (2012). How to design and evaluate research in education. (8. Ed.). New York: McGrawHill İnternational Edition.

Güzel, S. \& Yılmaz, S. (2020). 8. Sınıf öğrencilerinin üslü ifadeler konusundaki matematiksel dil kullanım düzeyleri ve dile ilişkin görüşleri. International Journal of Active Learning, 5(1), 33-56.

Hacıömeroğlu, G. (2009). Examining a preservice secondary teacher's growth: Implications for teaching. Journal of Theory and Practice in Education, 5(2), 261-273.

İymen, E., \& Paksu, A. (2015). 8. sınıf öğrencilerinin üslü ifadeler ile ilgili sayı duyularının sayı duyusu bileşenleri bakımından incelenmesi. Eğitim ve Bilim, 40(177), 109-125.

İymen, E. (2012). 8. sınıf öğrencilerinin üslü ifadeler ile ilgili sayı duyularının sayı duyusu bileşenleri bakımından incelenmesi. (Yayımlanmamış Yüksek Lisans Tezi). Pamukkale Üniversitesi Fen Bilimleri Enstitüsü, Denizli.

Kutluca, T. (2009). Identification of difficult subjects in ninth grade mathematics curriculum. Education Sciences, 4(2), 604-619.

MEB (2018). Matematik dersi öğretim programı (ilkokul ve ortaokul 1, 2, 3, 4, 5, 6, 7 ve 8. sinıflar). Ankara: Milli Eğitim Basımevi.

NCTM (2000). Curriculum and evaluation standards for school mathematics. Reston, VA: The Council.

Özaltun-Çelik, A. (2016). Temel matematiksel kavramlar ve uygulamaları. Ankara: Pegem Akademi. 
Özkan, E. M. \& Özkan, A. (2012). Misconception in exponential numbers in IST and IIND level primary school mathematics. Procedia - Social and Behavioral Sciences 46, 65 - 69.

Özkaya, M., Konyalığlu, A. C., \& Gedik, D. S. (2013). Matematik öğretmen adaylarının üslü ve köklü sayılar konusunda öğrencilerin sahip olabilecekleri hatalara yaklaşımları. Iğdır Üniversitesi Fen Bilimleri Enstitüsü Dergisi 3(2),49-54.

Özmantar, M. F., Bingölbali, E., \& Akkoç, H. (2008). Matematiksel kavram yanılgıları ve çözüm önerileri. Ankara: Pegem Akademi.

Paksu, A. (2008). Üslü sayılar ve köklü sayılar konusundaki öğrenme güçlükleri. Matematiksel kavram yanılgılar ve çözüm önerileri. Ankara: Pegem Akademi Yayıncılık.

Patton, M. Q. (2002). Two decades of developments in qualitative inquiry: A personal, experiential perspective. Qualitative social work, 1(3), 261-283.

Saraç, S. (2016). Üslü sayıların öğretiminde kullanılabilecek iki benzetim örneği: çamurlu ayakkabılar ve doktorhasta ilişkisi. Öğretim Atölyesi: Mesleki Gelişim Uygulamaları Dergisi, 1(1), 7- 9.

Sastre, M. T. M. \& Mullet, E. (1998). Evolution of the intuitive mastery of the relationship between base, exponent, and number magnitude in high-school students. Mathematical Cognition, 4(1), 67- 77.

Shulman, L. (1986). Those who understand: Knowledge growth in teaching. Educational Researcher, 15(2), 4-14.

Smith, J. P., diSessa, A. A., \& Roscheile, J. (1993). Misconceptions reconceived: A constructivist analysis of knowledge in transition. The Journal of the Learning Sciences, 3(2), 115-163.

Şimşek, H., \& Yıldırım, A. (2016). Sosyal bilimlerde nitel araştırma yöntemleri. Ankara: Seçkin Yayıncılık

Türnüklü, B. E. (2005). Matematik öğretmen adaylarının pedagojik alan bilgileri ile matematiksel alan bilgileri arasındaki ilişki. Eurasian Journal Of Educational Research, 21, 234-247.

Weber, K. (2002). Developing Students' Understanding of exponents and Logarithms. North American Chapter of the International Group for the Psychology of Mathematics Education, 1.

Yin, R. K. (2003). Designing case studies. In L. Maruster \& M. J. Gijsenberg (Eds.), Qualitative research methods (pp. 359-386). Washington DC: Sage. 


\section{Extended Abstract}

\section{Introduction}

One of the important key components affecting mathematics education is undoubtedly the teacher factor. Studies defining teacher knowledge and including the information that teachers should have were done by Shulman (Shulman, 1986). It was emphasized that among the things to be done for effective mathematics teaching having information about what students know and what they need is necessary to encourage them for learning better (NCTM, 2000). On the other hand, mathematics, is a course that involves many different subjects. The difficulty of these subjects is undoubtedly different for students. It is known that from these subjects students have difficulties in exponential expressions (Cengiz, 2006).Students begin to learn the concept of exponent for the first time in the Mathematics Lesson Curriculum with the 5th grade learning outcome (MEB, 2018). Students learn the subject of exponential expressions at the 6th, 7th, and 8th grades, as well as the continuation of 5th grade. In the literature, exponential expressions are seen as one of the issues that students make mistakes frequently and these mistakes can turn into misconceptions (Aydın, 2011; Cengiz, 2006; Gedik, Konyalığlu \& Özkaya, 2013; Sastre \& Mullet, 1998). It is thought that the difficulties and misconceptions are caused by three main reasons: psychological, pedagogical, and epistemological causes (Cornu,1991).

When the studies has been examined, it was seen that there were studies that included the difficulties encountered in exponential expressions, and there were also studies that included solution suggestions for them, but it was observed that there were few studies about taking precaution for prevent misconceptions. The aim of this study is to examine the opinions of middle school mathematics preservice teachers on the possible causes of misconceptions about exponential expressions and thinks to do to prevent these misconceptions. For this purpose, " What are the opinions of middle school mathematics preservice teachers for the possible causes of misconceptions in exponential expressions? " and "What are the opinions of middle school mathematics preservice teachers to prevent misconceptions in exponential expressions?" answers to these questions were sought.

\section{Method}

The case study method, one of qualitative research approaches, was used in the study. The study group was chosen from senior middle school mathematics teacher candidates studying at a state university in the Central Region. The study was carried out with 29 mathematics preservice teachers in the spring semester of the 2018-2019 academic year, and interviews were made with 9 of them who were volunteers. Criterion sampling, one of the purposeful sampling methods, was used in determining the participants. Participants were selected on a voluntary basis. The data were collected through the interview (question) form, which was prepared using the misconceptions found in the literature. While choosing the misconceptions, among the misconceptions put forward by Paksu (2008), 8 suitable for the middle school level were selected. Misconceptions encountered in the literature have been investigated. Expert opinion has been taken for the prepared interview form. The question form was applied to 29 preservice teachers by two researchers at one class hour. Later, interviews were made with 9 volunteers in detail. The audio recordings obtained from interviews with preservice teachers were listened to and first converted into a written text then analyzed with qualitative techniques. The codes and themes were tried to be determined from the forms and interviews in which the preservice teachers stated their reasons and opinions about their misconceptions about the exponents. For this, the content analysis technique, one of the qualitative analysis approaches, was used.

\section{Findings}

For the findings, possible causes were examined at first. These reasons are gathered under three headings. These are classified as pedagogical causes, psychological causes, and epistemological causes. For psychological reasons, it was stated that the student's lack of knowledge, not knowing what the base and exponent mean in exponential expressions, not knowing the numerical expansion of the exponential expression, not knowing the meaning and function of the parenthesis, not knowing the rule when the exponent is odd and double, and not understanding the meaning of the negative exponent may cause misconceptions. For pedagogical reasons; it was 
stated that due to the teachers' expression, generalization to multiplication in natural numbers, generalization of the division rule in exponential expressions to subtraction in exponential expressions, generalization of the rule in multiplication in exponential expressions to subtraction, generalization the displacement of factors in multiplication (change feature) to exponential expressions may be placed among the possible causes.

In addition, it was stated that epistemological causes originated from due to the difficulty in learning the exponential expressing conceptually. Considering the findings about the prevention of misconception in the study, it was observed that the pre-service teachers considered the precaution suggestions as a solution suggestion. This situation emerged in the interviews. Additionally, it was stated in the interviews the importance of explaining the concept through the activities for precautionary suggestion.

\section{Result and Discussion}

It was stated by the preservice teachers that students' lack of knowledge, not knowing what the base and exponent mean in exponential expressions, not knowing the numerical expansion of the exponential expression, not knowing the meaning and function of the parenthesis could cause misconceptions. In order to prevent misconceptions, they stated that more examples of exponential expressions should be resolved, concepts such as base and exponent should be emphasized at the beginning of the topic of exponential expressions, patterns should be used and multiple representations should be used while explaining the subject. It was observed that the precautionary suggestions were mostly given for pedagogical causes, and precautionary suggestion for psychological causes were not presented. Based on the results of the study, in order to contribute to the field in future studies, it is recommended to conduct detailed interviews with experienced middle school mathematics teachers regarding the causes of misconceptions encountered in the literature on exponential expressions and their precaution suggestions.

\section{Araştırmanın Etik Taahhüt Metni}

Yapılan bu çalışmada bilimsel, etik ve alıntı kurallarına uyulduğu; toplanan veriler üzerinde herhangi bir tahrifatın yapılmadığı, karşılaşılacak tüm etik ihlallerde "Manisa Celal Bayar Üniversitesi Eğitim Fakültesi Dergisi ve Editörünün" hiçbir sorumluluğunun olmadı̆̆ı, tüm sorumluluğun Sorumlu Yazara ait olduğu ve bu çalışmanın herhangi başka bir akademik yayın ortamına değerlendirme için gönderilmemiş olduğu sorumlu yazar tarafından taahhüt edilmiştir. 